\title{
Genetic control of the angular leaf spot reaction in common bean leaves and pods
}

\author{
Jerônimo Constantino Borel ${ }^{1}$, Magno Antonio Patto Ramalho ${ }^{2 *}$, Angela de Fátima Barbosa \\ Abreu $^{3}$, Lucas Gontijo Silva Maia ${ }^{1}$ \\ ${ }^{1} U F L A$ - Programa de Pós-Graduação em Genética e Melhoramento de Plantas. \\ ${ }^{2} U F L A$ - Depto. de Biologia, C.P. 3037 - 37200-000 - Lavras, MG - Brasil. \\ ${ }^{3}$ Embrapa Arroz e Feijão, C.P. 179 - Rod. GO-462 - km 12 - 75375-000 - Santo Antônio de Goiás, GO - Brasil. \\ *Corresponding author <magnoapr@dbi.ufla.br> \\ Edited by: Leonardo Oliveira Medici
}

\begin{abstract}
Information about genetic control of plant reaction to pathogens is essential in plant breeding programs focusing resistance. This study aimed to obtain information about genetic control of the angular leaf spot reaction in leaves and pods from common bean (Phaseolus vulgaris L.) line ESAL 686. This line was crossed with cultivars Jalo EEP 558 (resistant), Cornell 49-242 (resistant) and Carioca MG (susceptible). Generations $\mathrm{F}_{1}, \mathrm{~F}_{2}$ and backcrosses $\left(\mathrm{BC}_{11}\right.$ and $\mathrm{BC}_{21}$ ) were obtained. In the dry season (2009), parents and respective populations were evaluated for angular leaf spot reaction under field conditions. Disease severity was evaluated on leaves and pods using diagrammatic scales. Severity scores were obtained and mean and variance genetic components were estimated for both. Segregation of $\mathrm{F}_{2}$ generation was analyzed for some crosses. Different genes control angular leaf spot reaction in leaves and pods. Mean and variance components showed predominance of additive effects. Heritability was high, however, was greater on pods than on leaves which indicated that leaf reaction is more influenced by the environment.
\end{abstract}

Keywords: Pseudocercospora griseola, plant disease resistance, plant breeding, genetic control

\section{Introduction}

Angular leaf spot caused by Pseudocercospora griseola (Sacc.) Crous and $\mathrm{U}$. Braun is one of the most important and widely distributed diseases of common bean (Phaseolus vulgaris L.) in producing regions (Sartorato and Alzate-Marin, 2004; Damasceno-Silva et al., 2008). Breeding for resistance has found some difficulties due the great pathogenic variability and absence of genetic control information for some lines (Sartorato, 2002). Information about genetic control is very useful, because it helps breeders to choose the most efficient strategies to make it possible to obtain resistant and productive cultivars.

At least 14 genes were identified in which the resistance was attributed to dominant and/or recessive alleles (Mahuku et al., 2009). The assessment of disease reaction is usually made in the leaf, when plants show the first trifoliate fully expanded. However, it has been observed that reaction to the angular leaf spot varies depending on the plant organ. In the bean breeding program at the Universidade Federal de Lavras, the line ESAL 686 was obtained some years ago. This line has yellow large grains, determined habit, early cycle and draws attention for symptoms of angular leaf spot on leaves, but not on pods.

Due the high pathogenic variability of $P$. griseola, the search and characterization of new sources of resistance became indispensable, as well as understanding the genetics of the reaction to the pathogen. Thus, this work was performed in order to study the genetic control of the reaction of the bean angular leaf spot, on leaves and pods and estimate some genetic parameters of interest for breeding.

\section{Materials and Methods}

The experiment was carried in Lavras, State of Minas Gerais, Brazil. Line ESAL 686 was crossed with cultivars Cornell
49-242, Jalo EEP 558 and Carioca MG. Cultivar Jalo EEP 558 is a Andean bean, with large grains and resistance to several $P$. griseola races. The Cornell 49-242 cultivar is from Mesoamerican origin, black and small grain and it is a source of resistance to angular leaf spot (Caixeta et al., 2005). The Carioca MG cultivar has similar traits to Mesoamerican beans, with small grains, carioca type and susceptible to angular leaf spot.

Three hybrid combinations were obtained: ESAL $686\left(\mathrm{P}_{1}\right) \times$ Cornell 49-242; ESAL $686 \times$ Carioca MG and ESAL $686 \times$ Jalo EEP 558. For each combination the $\mathrm{F}_{2}$ generation was obtained and also the backcrosses with ESAL $686\left(\mathrm{BC}_{11}\right)$ and others cultivars $\left(\mathrm{BC}_{21}\right)$. During the dry season of 2009 , parental lines, $\mathrm{F}_{1}$ and $\mathrm{F}_{2}$ generations and the backcrosses were evaluated under field conditions with natural occurrence of the pathogen. The experiment was carried in a randomized block design, with two replicates. Twenty plants from parental lines and $\mathrm{F}_{1}, 160$ plants from $\mathrm{F}_{2}$ generation and 40 plants from each backcross $\left(\mathrm{BC}_{11}\right.$ and $\mathrm{BC}_{21}$ ) were used per each replicate. Fifteen days before sowing these populations, a border with the susceptible cultivar (Carioca) was sown to obtain a source of inoculum, which allowed a uniform occurrence of the disease in the experimental area.

During the phenological stage R7 (pod filling), disease severity was assessed on leaves using a diagrammatic scale of nine degrees proposed by Godoy et al. (1997): Values in parenthesis refer the percentage of diseased leaf area: 1 (until $0.2 \%) ; 2$ (0.4 \%); 3 (0.9\%); 4 (1.7\%); 5 (3.2\%); 6 (6 \%); 7 (10.7\%); 8 (18.7 $\%)$ and $9(30.4 \%)$. Scores were assigned by two evaluators. In June of 2009, plants of each population were harvested (uprooted and tied) and stored in a warehouse to natural drying for seven days. Four pods were randomly collected per plant of each population $\left(\mathrm{P}_{1}, \mathrm{P}_{2}, \mathrm{~F}_{1}, \mathrm{~F}_{2}, \mathrm{BC}_{11}\right.$ and $\left.\mathrm{BC}_{21}\right)$ at the cross ESAL 686 $\times$ Carioca MG. Pods were identified and arranged in a laboratory bench where five evaluators assessed the angular leaf spot 
severity using a diagrammatic score of nine degrees described below: 1 - Absence of pod symptoms; 2 - Symptoms covering 5 $\%$ of pod surface; 3 - Symptoms covering $10 \%$ of pod surface; 4 - Symptoms covering $20 \%$ of pod surface; 5 - Symptoms covering $40 \%$ of pod surface; 6 - Symptoms covering $60 \%$ of pod surface; 7 - Symptoms covering $80 \%$ of pod surface; 8 - Symptoms covering $90 \%$ of pod surface and 9 - symptoms covering more than $95 \%$ of pod surface. For the other crosses $($ ESAL $686 \times$ Cornell 49-242 and ESAL $686 \times$ Jalo EEP 558) 10 pods per plant were assessed. In this case, assessments were performed by two evaluators.

Data of the $\mathrm{F}_{2}$ generation were analyzed for contrasting crosses, for both leaf and pod severities. Individual plants were considered resistant when the average score was $\leq 3$. Mean and variance components were estimated considering an additivedominant model (without epistasis) as described by Cruz et al. (2004). For some crosses, heritability estimates were obtained in the broad and narrow sense, as well the associated errors according Vello and Vencovsky (1974).

\section{Results and Discussion}

Parental lines used in this study were different in the disease reaction and confirmed their known reactions (Table 1). Cornell 49-242 and Jalo EEP 558 cultivars showed resistance to the pathogen, ESAL 686 line showed intermediate reaction and Carioca MG was confirmed to be susceptible. Average of the $\mathrm{F}_{1}$ generation was in general intermediate between the parental lines and similar to the $\mathrm{F}_{2}$ generation.

A coevolution is described between the common bean and some pathogens from distinct regions as Andes and Central America, mainly for P. griseola fungus (Guzman et al., 1995; Pastor-Corrales and Jara, 1995). Thus, it is expected that the angular leaf spot reaction will be different according to the origin group of the cultivar. However, in this study, no difference was found in the reaction between Cornell 49-242 cultivar (Mesoamerican) and Jalo EEP 558 (Andean). Both were resistant to $P$. griseola.

Segregation analysis of the $\mathrm{F}_{2}$ generation for the crosses between ESAL 686 and Cornell 49-242 and Jalo EEP 558 cultivars, showed a ratio of three resistant plants to one susceptible (3:1). For all cases, the Chi-square test was not significant which indicated the occurrence of monogenic inheritance where the dominant allele is responsible for the resistance (Table 2). Jalo EEP 558 cultivar has one gene with a dominant allele for resistance that is used as a source of resistance to the angular leaf spot in south Minas Gerais state, Brazil, for more than 30 years (Teixeira et al., 2005). Resistance of Cornell 49-242 cultivar is also due to a dominant allele (Caixeta et al., 2005).

Resistance inheritance of the common bean to angular leaf spot has shown to be complex in some situations. The genetic control of reaction in some lines was observed to vary according to the used susceptible parental and pathotype. A single gene with dominant allele was observed for the resistance to pathotype 63-19 when the line México 54 was crossed with the Rudá cultivar (Mesoamerican) (Sartorato et al., 1999). Otherwise, Mahuku et al. (2002) described the resistance of line México 54 to pathotype 31-55 as a single gene with the resistance due the recessive allele, when crossed with a snap bean cultivar. Another fact that stands out is the continuous response to phenotypic recurrent selection for resistance to the angular leaf spot (Amaro et al., 2007). In the genetic control of resistance to the angular leaf spot minor genes could be involved that were environmental influenced, in addition to major genes or modifier genes. This fact could explain the partial resistance in some lines, including ESAL 686, that had continuous distribution of this character. In this case, utilization of quantitative genetic models such as mean

Table 1 - Mean severity of the angular leaf spot in leaves $(\mathrm{L})$ and pods $(\mathrm{P})$ from crosses between ESAL $686\left(\mathrm{P}_{1}\right)$ and three common bean cultivars $\left(\mathrm{P}_{2}\right)$ and respective populations.

\begin{tabular}{|c|c|c|c|c|c|c|c|c|}
\hline \multirow[b]{2}{*}{ Crosses } & \multirow[b]{2}{*}{ Organ } & \multirow[b]{2}{*}{ Reaction* } & \multicolumn{6}{|c|}{ Mean of severity } \\
\hline & & & $\mathrm{P}_{1}$ & $\mathrm{P}_{2}$ & $\mathrm{~F}_{1}$ & $\mathrm{~F}_{2}$ & $\mathrm{RC}_{11}$ & $\mathrm{RC}_{21}$ \\
\hline ESAL $686 \times$ Jalo EEP 558 & $\mathrm{~L}$ & $\mathrm{I} \times \mathrm{R}$ & 3.42 & 2.05 & 2.53 & 3.03 & 3.52 & 2.90 \\
\hline ESAL $686 \times$ Cornell 49-242 & $\mathrm{L}$ & $\mathrm{I} \times \mathrm{R}$ & 3.42 & 2.47 & 2.5 & 3.27 & 3.51 & 2.0 \\
\hline ESAL $686 \times$ Carioca MG & $\mathrm{L}$ & $\mathrm{I} \times \mathrm{S}$ & 3.42 & 7.37 & 6.31 & 5.60 & 3.79 & 5.50 \\
\hline ESAL $686 \times$ Carioca MG & $\mathrm{P}$ & $\mathrm{R} \times \mathrm{S}$ & 1.0 & 8.05 & 1.21 & 2.5 & 1.15 & 3.23 \\
\hline ESAL $686 \times$ Cornell 49-242 & $\mathrm{P}$ & $\mathrm{R} \times \mathrm{R}$ & 1.0 & 1.31 & 1.07 & 1.15 & 1.03 & 1.23 \\
\hline ESAL $686 \times$ Jalo EEP 558 & $\mathrm{P}$ & $\mathrm{R} \times \mathrm{R}$ & 1.0 & 1.0 & 1.0 & 1.0 & 1.0 & 1.0 \\
\hline
\end{tabular}

*R: Resistant (<3); I: Intermediate (3 - 6) and S: Susceptible (> 6).

Table 2 - Segregation of the $\mathrm{F}_{2}$ generation from crosses between ESAL 686 and three common bean cultivars regarding severity to angular leaf spot (Pseudocercospora griseola) in leaves and pods.

\begin{tabular}{|c|c|c|c|c|c|}
\hline \multirow{2}{*}{ Population } & \multirow{2}{*}{ Organ } & Expected ratio & Observed ratio & \multirow{2}{*}{$\chi^{2}$} & \multirow{2}{*}{$p$} \\
\hline & & $\mathrm{R}: \mathrm{S}$ & $\mathrm{R}: \mathrm{S}$ & & \\
\hline $\mathrm{F}_{2}(\mathrm{ESAL} 686 \times$ Jalo EEP558) & Leaves & $3: 1$ & $170: 54$ & 0.09 & $0.7576^{\mathrm{NS}}$ \\
\hline $\mathrm{F}_{2}($ ESAL $686 \times$ Cornell 49-242) & Leaves & $3: 1$ & $149: 63$ & 2.52 & $0.1127^{\mathrm{NS}}$ \\
\hline $\mathrm{F}_{2}($ ESAL $686 \times$ Carioca MG $)$ & Pods & $3: 1$ & $144: 46$ & 0.04 & $0.8340^{\mathrm{NS}}$ \\
\hline
\end{tabular}

${ }^{\mathrm{NS}}$ Non-significant $(t$ test, $p<0.05)$. 
and variance components provides more reliable information about the mode of gene action and allows obtaining estimates of useful genetic parameters for breeding.

The additive - dominant model used in this study to estimate mean components showed a good adjustment and was sufficient to explain the observed variation. Estimates of determination coefficients $\left(\mathrm{R}^{2}\right)$ were higher than $99 \%$ (Table 3), estimating " $m$ " (phenotypic average of parents or mean point), " $a$ " (deviations of homozygotes for the mean point or additive effect) and " $d$ " (deviations of the heterozygotes from the mean point, or dominance effect). There was predominance of additive effects in the control of the reaction to angular leaf spot in leaves (Table 3). Estimates of the " $a$ " component were different from zero, which could be observed by their low magnitude of associated standard error, while estimates of " $d$ " were not different from zero. Similar results were described by Mendonça et al. (2003) where the authors observed the leaf reaction to angular leaf spot, the additive effects were more important than dominance effects. For the ESAL $686 \times$ Carioca MG cross, estimate of " $a$ " was negative. This could be explained by the fact that line ESAL 686 showed a lower severity than the Carioca MG cultivar.

Additive genetic variance estimates $\left(\hat{\sigma}_{A}^{2}\right)$ were greater than dominance genetic variance $\left(\hat{\sigma}_{D}^{2}\right)$. The $\hat{\sigma}_{D}^{2}$ could be considered null in the cross ESAL $686 \times$ Carioca MG, since the lower limit of confidence interval was negative (Table 4). It is worth mentioning that when the variance is used, estimates could have associate errors of high magnitude, which requires careful interpretation of the results (Vello and Vencovsky, 1974).

Heritability in the broad and narrow senses for the crosses ESAL 686 × Jalo EEP 558 and ESAL $686 \times$ Cornell 49242 is shown in Table 6 . Estimates could be considered high and in agreement with previous results. Estimates ranged from $55 \%$ to $77 \%$ in the broad sense and from $19 \%$ to 68 $\%$ in the narrow sense in a study conducted by Mendonça et al. (2003). The heritability is not immutable, depends on the population and environmental conditions in which individuals were grown (Bernardo, 2002).
ESAL 686 line and Jalo EEP 558 cultivar did not show symptoms in the pods. The Cornell 49-242 cultivar had some mild symptoms, however it was considered resistant. Thus, crosses involving these three cultivars as parental did not show segregation. Carioca MG cultivar was confirmed as susceptible in the pods and presented a contrasting reaction with the ESAL 686 line. Therefore, greater emphasis was placed on results involving this cross (ESAL $686 \times$ Carioca MG) and their respective generations. It was observed that severity averages of the $\mathrm{F}_{1}$ generation as the $\mathrm{BC}_{11}\left(\mathrm{~F}_{1} \times \mathrm{ESAL} 686\right)$, were similar to ESAL 686 (resistant). Otherwise, the susceptible backcross $\left(\mathrm{BC}_{21}\right)$ had high severity (Table 1). Segregation of the $\mathrm{F}_{2}$ generation was three resistant plants to one susceptible; the Chi-square test was not significant, which indicates a monogenic inheritance conditioned by a dominant allele (Table 2).

Mean components estimates showed the presence of additive and dominance effects in the control of this character. Estimate of the dominance effect " $d$ " was negative indicating dominance in the sense of decrease the score of severity and consequently increase the resistance (Table 5). Determination coefficients $\left(\mathrm{R}^{2}\right)$ in the used model were high, which indicates a good adjustment of the model to explain the observed variation. This is an indication that the genetic control of reaction to angular leaf spot of bean pods does not occur epistasis (Ramalho et al., 1993).

Variance component estimates of the severity score in the pods reinforces the hypothesis of dominance in the control of character (Table 5). Additive variance $\left(\hat{\sigma}_{A}^{2}\right)$ and dominance variance $\left(\hat{\sigma}_{D}^{2}\right)$ were higher than environmental variance estimate $\left(\hat{\sigma}_{E}^{2}\right)$. Confidence interval was of low magnitude and the lower limit was positive, which indicates that the estimates were different from zero. Apparently, dominance effects were more important in pods than in leaves. For families derived from the cross between Pérola and Carioca MG cultivars the gene action was different in leaves and pods. Dominance effects were detected only in pods while additive effects were significant for both organs (Mendonça et al., 2003).

Table 3 - Mean component estimates for angular leaf spot reaction in bean leaves, dominance ratio $(d / a)$ and coefficient of determination $\left(\mathrm{R}^{2}\right)$.

\begin{tabular}{|c|c|c|c|c|c|}
\hline \multirow{2}{*}{ Crosses } & \multicolumn{3}{|c|}{ Mean Components \pm Standard error } & \multirow{2}{*}{$d / a$} & \multirow{2}{*}{$\mathrm{R}^{2}$} \\
\hline & $\hat{m}$ & $\hat{a}$ & $\hat{d}$ & & \\
\hline ESAL $686 \times$ Jalo EEP 558 & $2.98 \pm 0.10^{*}$ & $0.80 \pm 0.10^{*}$ & $-0.17 \pm 0.17^{\mathrm{NS}}$ & 0.21 & 99.33 \\
\hline ESAL $686 \times$ Cornell 49-242 & $3.24 \pm 0.11 *$ & $0.66 \pm 0.12 *$ & $-0.48 \pm 0.18^{\mathrm{NS}}$ & 0.73 & 99.16 \\
\hline ESAL $686 \times$ Carioca MG & $5.27 \pm 0.16^{*}$ & $-1.96 \pm 0.16^{*}$ & $0.27 \pm 0.36^{\mathrm{NS}}$ & 0.13 & 99.39 \\
\hline
\end{tabular}

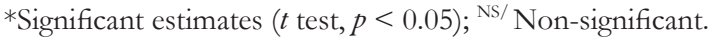

Table 4 - Variance components estimates to angular leaf spot reaction in bean leaves and coefficient of determination $\left(\mathrm{R}^{2}\right)$.

\begin{tabular}{lcccc}
\hline & \multicolumn{4}{c}{ Variance components and confidence intervals } \\
\cline { 2 - 5 } Crosses & $\hat{\sigma}_{A}^{2}$ & $\hat{\sigma}_{D}^{2}$ & $\hat{\sigma}_{E}^{2}$ & $\mathrm{R}^{2}$ \\
\hline ESAL 686 $\times$ Carioca MG & $5.21 *[4.34 ; 6.37]$ & $-0.92^{\mathrm{NS}}[-1.19 ;-0.79]$ & $2.22 *[1.63 ; 3.16]$ & 97.83 \\
ESAL 686 $\times$ Cornell 49-242 & $1.25 *[0.95 ; 1.71]$ & $0.01^{\mathrm{NS}}[0.003 ; 0.06]$ & $0.81 *[0.63 ; 1.10]$ & 97.76 \\
ESAL 686 $\times$ Jalo EEP 558 & $1.06 *[0.89 ; 1.28]$ & $0.26^{\mathrm{NS}}[0.21 ; 0.34]$ & $0.66 *[0.50 ; 0.92]$ & 95.98 \\
\hline
\end{tabular}

*Significant estimates ( $t$ test, $p<0.05)$; ${ }^{\text {NS/ }}$ Non-significant. 
Table 5 - Mean and Variance genetic component estimates for the angular leaf spot reaction in bean pods at the cross ESAL $686 \times$ Carioca MG.

\begin{tabular}{cccc}
\hline $\begin{array}{c}\text { Mean } \\
\text { components }\end{array}$ & $\begin{array}{c}\text { Estimates } \pm \\
\text { Standard error }\end{array}$ & $\begin{array}{c}\text { Variance } \\
\text { components }\end{array}$ & $\begin{array}{c}\text { Estimates and } \\
\text { confidence interval }\end{array}$ \\
\hline$\hat{m}$ & $4.46 \pm 0.04^{*}$ & $\hat{\sigma}_{A}^{2}$ & $1.57^{1}[1.31 ; 1.91]$ \\
$\hat{a}$ & $-3.46 \pm 0.04^{*}$ & $\hat{\sigma}_{D}^{2}$ & $0.22^{1}[0.17 ; 0.29]$ \\
$\hat{d}$ & $-3.28 \pm 0.07^{*}$ & $\hat{\sigma}_{E}^{2}$ & $0.15^{*}[0.11 ; 1.21]$ \\
$d / a$ & 0.95 & - & - \\
$\mathrm{R}^{2}$ & 99.99 & $\mathrm{R}^{2}$ & 86.79 \\
\hline
\end{tabular}

*Significant estimates $(t$ test, $p<0.05) ;{ }^{* 1 /}$ Significant estimates $(t$ test, $p<0.1)$.

Heritability estimates observed in pods, in the broad and narrow sense, were higher than heritability estimates in leaves (Table 6), which indicate that the severity assessment in pods had more precision. Probably, this must be related to the assessment of pods on benches while leaves were assessed under field conditions. Correlation between severity in pods and leaves was not significant. According to the results obtained in this work, we conclude that different genes control the reaction of the bean angular leaf spot on leaves and pods.

\section{Acknowledgement}

To CNPq, for the financial support.

\section{References}

Amaro, G.B.; Abreu, A.F.B.; Ramalho, M.A.P. 2007. Phenotypic recurrent selection in the common bean (Phaseolus vulgaris L.) with carioca-type grains for resistance to the fungi Phaeoisariopsis griseola. Genetics and Molecular Biology 30: 584-588.

Bernardo, R. 2002. Breeding for Quantitative Traits in Plants. Stemma Press, Woodburry, MN, USA.

Caixeta, E.T.; Borém, A.; Alzate-Marin, A.L.; Fagundes, S.D.; Silva, M.; Barros, E.G.; Moreira, M.A. 2005. Allelic relationships for genes that confer resistance to angular leaf spot in common bean. Euphytica 145: $237-245$

Cruz, C.D.; Regazzi, A.J.; Carneiro, P.C.S. 2004. Biometrical Models Applied to Genetic Improvement. 3ed. UFV, Viçosa, MG, Brazil (in Portuguese).

Damasceno-Silva, K.J.; Souza, E.A.; Sartorato, A.; Freire, C.N.S. 2008. Pathogenic variability of isolates of Pseudocercospora griseola, the cause of common bean angular leaf spot, and its implications for resistance breeding. Journal of Phytopathology 156: 602-606.

Godoy, C.V.; Carneiro, S.; Iamauti, M.T.; Dallapria, M.; Amorim, L.; Berger, R.D.; Bergamin, A. 1997. Diagrammatic scales for bean diseases: development and validation. Zeitschrift Fur Pflanzenkrankheiten Und Pflanzenschutz 104: 336-345.
Table 6 - Heritability estimates in broad $\left(\hat{h}_{a}^{2}\right)$ and narrow senses $\left(\hat{h}_{r}^{2}\right)$ for the reaction to the angular leaf spot (Pseudocercospora griseola) in bean leaves and pods.

\begin{tabular}{lccc}
\hline \multirow{2}{*}{ Crosses } & \multirow{2}{*}{ Organ } & \multicolumn{2}{c}{ Estimate \pm Associate error } \\
\cline { 3 - 4 } & & $\hat{h}_{a}^{2}$ & $\hat{h}_{r}^{2}$ \\
\hline ESAL 686 $\times$ Cornell 49242 & Leaves & $0.61 \pm 0.08$ & $0.60 \pm 0.41$ \\
ESAL 686 $\times$ Jalo EEP 558 & Leaves & $0.67 \pm 0.07$ & $0.53 \pm 0.25$ \\
ESAL 686 $\times$ Carioca MG & Pods & $0.92 \pm 0.05$ & $0.81 \pm 0.30$ \\
\hline
\end{tabular}

Guzman, P.; Gilbertson, R.L.; Nodari, R.; Johnson, W.C.; Temple, S.R.; Mandala, D.; Mkandawire, A.B.C.; Gepts, P. 1995. Characterization of variability in the fungus Phaeoisariopsis-griseola suggests coevolution with the common bean (Phaseolus-vulgaris). Phytopathology 85: 600-607.

Mahuku, G.S.; Iglesias, A.M.; Jara, C. 2009. Genetics of angular leaf spot resistance in the Andean common bean accession G5686 and identification of markers linked to the resistance genes. Euphytica 167: 381-396.

Mahuku, G.S.; Jara C.; Cuasquer, J.B., Castellanos, G. 2002. Genetic variability within Phaeoisariopsis griseola from Central America and its implications for resistance breeding of common bean. Plant Pathology 51: 594-604.

Mendonça, H.A.; Santos, J.B.; Ramalho, M.A.P. 2003. Genetic control of common bean reaction to angular leaf spot. Crop Breeding and Applied Biotechnology 3: 209-226.

Pastor-Corrales, M.A.; Jara, C. 1995. The evolution of Phaeoisariopsis griseola with common bean in Latin America. Fitopatologia Colombiana 19: 15-22 (in Spanish, with abstract in English).

Ramalho, M.A.P.; Santos, J.B.; Zimmermann, M.J.O. 1993. Quantitative Genetics in Autogamous Plants: Applications to Genetic Improvement of Common Bean. UFG, Goiânia, GO, Brazil (in Portuguese).

Sartorato, A. 2002. Identification of Phaeoisariopsis griseola pathotypes from five States of Brazil. Fitopatologia Brasileira 27: 78-81.

Sartorato, A.; Alzate-Marin, A.L. 2004. Analysis of the pathogenic variability of Phaeoisariopsis griseola in Brazil. Annual Report of the Bean Improvement Cooperative 47: 235-236.

Sartorato, A., Nietsche, S., Barros, E.G.; Moreira, M.A. 1999. Scar markers linked to angular leaf spot resistance gene in common bean. Annual Report of the Bean Improvement Cooperative 42: 21-22.

Teixeira, F.F.; Santos, J.B.; Ramalho, M.A.P.; Abreu, A.F.B.; Guimarães, C.T.; Oliveira, A.C. 2005. QTL mapping for angular leaf spot in common bean using microsatellite markers. Crop Breeding and Applied Biotechnology 5: 272-278.

Vello, N.; Vencovsky, R. 1974. Variances associated to estimates of genetic variance and heritability coefficients. p.238-248. In: Scientific Reports of the Genetics Department/ESALQ, Piracicaba, SP, Brazil (in Portuguese).

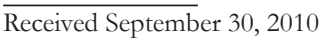

Accepted April 18, 2011 